\title{
The Trapped Female Breaking Loose: William Faulkner's "Elly" (1934).
}

By

Hans H. Skei

University of Oslo

"Elly" is one of the many stories in Faulkner's second collection of short stories, Doctor Martino and Other Stories, where a young girl in conflict with her parental authorities is the protagonist, and Elly is in fact more outspoken and goes further in her opposition to her guardians than any other girl in Faulkner's short fiction. This kind of conflict is found in many of Faulkner's stories, and it is found most frequently in his very early short fiction, notably in the stories written before $1930 .{ }^{1}$ Elly is akin to the very young girl in the unpublished early story "Adolescence," to Miss Zilphia in "Miss Zilphia Gant," to Louise King in "Doctor Martino," and to numerous other girls. ${ }^{2}$ The scene in the shrubs on the lawn of the "biggish house" where Elly lives is very similar to the same in flagranti scenes with feelings of guilt and thoughts of revenge in "Adolescence," in "Nympholepsy," and even in Faulkner's first novel, Soldiers' Pay. ${ }^{3}$ Faulkner has apparently taken a special interest in this kind of extreme juxtaposition of the young, burning desire and the society which cherishes and values virginity and innocencenot the least as a means of gaining and maintaining control over the upcoming generation. The criticism of a hostile society which limits a woman's possibilities to little but home and marriage is stronger and more direct in "Elly" than what is common in most of Faulkner's works, ${ }^{4}$ but some of the criticism misses its aim by being limited to a representative of an older generation: Elly's grandmother. Since Elly overreacts so that she becomes sexually promiscuous - a typical "flapper" - some criticism of her behaviour is implicit in the text. But it would be wrong to make this the major focus of one's 
interpretation. Elly is a young girl who experiences great difficulties while passing from childhood to womanhood. She is unable to cope with an adult world where one's freedom of choice is severely curtailed by traditions and expectations, and by social and sexual taboos. Elly is not "a bundle of the very traits which he [Faulkner] utterly despises," as Bradford puts it; ${ }^{5}$ and even if she is "corrupt" (a description Irving Malin uses about Elly and a few other of Faulkner's women ${ }^{6}$ ), the author leaves no doubt about some of the influences which are responsible for her conduct. Elly does not act out of some natural badness, and it would be unfair to condemn her for not adjusting to an old-fashioned role when this role is described in very negative terms in the text. That elements of a generation conflict also may be detected in "Elly," does not reduce the importance of trying to assess adequately the social context in which Elly is placed.

The young girls in Faulkner's early stories find different solutions to the threat from the grown-ups: in "Adolescence" a kind of armistice and a blocking of one's own ego; in "Miss Zilphia Gant" armistice, hard work, and then, when the one opportunity comes, a short-lived rebellion; in Soldiers' $P$ ay a dream and a vain hope, cherished in complete secrecy and followed by frustration. Typical for all of these characters is a silent acquiescence to what the authorities require, an apparent reconciliation with the prescribed role. Unlike the other girls, Elly directs her revenge outward, and she retaliates by killing her grandmother, even when this also leads to the death of her lover, and, by implication, of herself.

The affinities with other early short stories discussed briefly above are not surprising when we know that "Elly" was written at least before February 23, 1929.7 From a number of different versions in the early thirties, Faulkner revised his story substantially into a manuscript which he entitled "Elly," and the published story is a further, although less substantial, revision of this manuscript. "Elly" was published in Story for February 1934, and thus appeared in this periodical only a few months before its publication as one of the fourteen stories in Doctor Martino and Other Stories. ${ }^{8}$

"Elly" is in part located to Jefferson, but Faulkner refrains from using a community point of view or a first-person narrator who is more or less a spokesman for the town, as he does in a number of stories set in his imaginary town. "Elly" is narrated by an omniscient author, but the angle of vision is mostly with Elly herself so that we get very few unbiased portraits and interpretations of the other 
characters in the story. This is clearly a disadvantage, especially in the case of Elly's grandmother. The grandmother represents tradition, authority, and an old-fashioned, rigid female role or code of behaviour, and Elly is juxtaposed against this character. The conflict between Elly and her grandmother may well appear to be the most salient feature of the over-all conflict in the story, but the text proves that this is not quite so. Elly's hatred is directed against her grandmother, but it is nevertheless in part displaced aggression: her parents, of whom she demonstrably is afraid, and the society which in her opinion has nothing to offer her, are the real opponents. Only once, however, is this clear in the story; after Elly has been discovered with Paul on the lawn she is afraid that her grandmother has told her parents what she has done, but when she realizes that the grandmother has said nothing, she also understands that the old, implacable woman uses this knowledge as a means of controlling and ruling her. Her outburst in this situation is not so much directed against the grandmother, Ailanthia, whose impossible name Elly has inherited, as it demonstrates her own frustration and the immediate causes she finds for it, and hence for her own sexual misconduct:

"What else can I do, in this little dead, hopeless town? I'll work. I don't want to be idle. Just find me a job - anything, anywhere, so that it's so far away that I'll never have to hear the word Jefferson again'" (248). ${ }^{9}$

The basic conflict of the story is thus established - a conflict between a young girl who naturally expects and hopes for more in life than what she has found Jefferson can give, and, on the other side, a non-permissive society which is depicted as being injurious if not destructive to a number of young women in Faulkner's stories.

The omniscient author tells the story about Elly's past and present by recounting the trip she makes to fetch her grandmother back home from a stay she has had in Mills City. The opening paragraphs show Elly and Paul approaching the city, and then lingers for some time on the wooden railings alongside the curving road. Without explicitly saying so, the author nevertheless hints that the couple have been making love in the woods recently. In Elly's attempts to remember something completely forgotten, the grandmother suddenly comes to her mind and is thus presented to the readers from Elly's point of view.

The first page of the story thus introduces Elly, the inadequate railing along what might become a dangerous road, and the illicit 
relationship between Paul and Elly. But in all the speed and blur of the opening paragraphs, the grandmother is also portrayed with her "dead hearing and inescapable cold eyes" (243), before the narrator in a ten pages long flashback reveals Elly's general situation and accounts for the events leading up to the trip she is now taking.

After the flashback, the story is brought back to the present time and then continued through the car "accident" on the way home from Mills City - on the very same spot as the story opened. In between we have witnessed a series of almost incredible events unfold. They are loosely motivated in the flashback section, and are then set in terrific and terrifying motion in the last scenes - till the motion is brutally halted and EIly in all her childishness and helplessness and despair is exposed in a deadly tableau.

Elly is one of many sexually active female characters in Faulkner's fiction - within certain limits - and she is one of the few, if not the only one, coming from what seems to be the upper class in Jefferson who rebels against her alleged role as a woman. Women of the lower classes may be sexually active and natural in their behaviour, because their role is less rigidly prescribed and watched over. Elly, on the other hand, lives in a big house, with "a deep veranda with screening vines and no lights" (243). The house is isolated, dark, and withdrawn from the outside world, and Elly feels trapped in it - a feeling that is strengthened by her grandmother's vigilance. Elly has most certainly magnified her grandmother's antagonism and watch-keeping; her reactions are also reflections of her own uncertainty and a projection of her own hatred. ${ }^{10} \mathrm{It}$ is also important to understand that the conflict in "Elly" is not a result of Elly's having an affair with a Negro, even if nobody knows for certain that Paul has Negro blood in him. This element, which is so central to the novel Light in August, functions to make the antagonism paramount. Elly can strike back at her grandmother by doing something really bad and provocative, and the narrator can put old Ailanthia in a bad light by showing her racial prejudice. Paul, beside being an impossible match for Elly, is mainly used by her as a means to get away from Jefferson. But Paul, either because he sees through Elly or simply because he is a male chauvinist, wants nothing but Elly's body: "I don't marry them, I tell you' (249) should have been a revealing statement to Elly, but Paul apparently represents Elly's only chance of breaking loose from Jefferson and stifling parental guidance, and accordingly she is unwilling to give him up. The attraction and excitement aroused by the forbidden Paul 
add important elements to the story, as it appears that more girls than just Elly feels drawn toward him. Elly, despite all her frantic sexuality and all her flirtatiousness, may be said to compensate for what she feels life should have been - by competing with other girls, and by reacting strongly against the code of conduct represented by her grandmother who is "implacably chaste" (246), and who in Elly's almost paranoid sense of being watched and suspected seems to be "the only other actually living person in it [the house]" (250). The wording here is important: It is implied that Elly's parents are not living; meaning that they live the accepted, correct and monotonous life they are supposed to. For a period after Paul has left her, Elly relinquishes all hope of change and improvement, too. Like Juliet in "Adolescence" and Zilphia in "Miss Zilphia Gant" she accepts armistice as she "passed the monotonous rounds of her days in a kind of dull peace" (210; my emphasis). She submits to becoming engaged to Philip, assistant cashier in a bank, "a grave, sober young man of impeccable character and habits". (250), who in allowing Elly to let Paul drive her to fetch the grandmother in Mills City instead of doing it himself, demonstrates male stupidity as well as an admirable trust in his fiancée. The wedding is only three weeks away, and Elly's behaviour during the trip is a last desperate and wilfull attempt to get away from the boring, tedious, dull life lying in wait for her. Her temporary acquiescence was never genuine, as her own thoughts reveal: "At least I can live out the rest of my dead life as quietly as if I were already dead" (250). ${ }^{\mathbf{1 1}}$

Elly still hopes that Paul will marry her and take her away from Jefferson, and when he refuses to do so, her solution is to kill him and to kill her grandmother who has made the relationship to Paul impossible as Elly sees it. Elly unquestionably wants to get rid of her grandmother in some way or other, but it is Paul's final refusal to marry her that makes her force the car out of the road. Marriage to a man of "impeccable character" and a dull suburban life is a future so unbearable to Elly that she apparently feels she can sentence other people to death if they will not help her to escape. But Elly's solution is, of course, no solution at all. Aside frcm being criminal, it solves no problems, and Elly's frustration is both misplaced and wrongheaded. We can, vaguely, understand and perhaps even accept her frustration and despair. The murderous car-crash shows on one level how desperate and hence destructive a life like Elly's can make a person, and, on a different level, it shows how useless it is to react as Elly does. And even if much of Elly's be- 
haviour can be seen as a reaction to her grandmother, Elly also acts on her own. Elly is trapped, and her defiance of her grandmother's rules and regulations is also an assertion of her own will. But Elly cannot break loose in any meaningful and positive sense by striking back blindly. As Faulkner has shown indirectly by presenting women in similar situations in a number of stories, Elly's predicament is by no means unique, but nothing in the story indicates that Elly is aware of this. Her attempt to break loose and establish a better life for herself is therefore an individual's isolated attempt to fight a whole social system, and the attempt is doomed to failure. Within the context of the story, no answer to Elly's problems is suggested, no solution even hinted at. The urge, the need, the desperation to be alive in any meaningful sense is given a fictional account. In its final horror, this portrait of another young and wilfull Faulknerian flapper, might be compared briefly to other women belonging to the same social level in the small and dull town of Jefferson. All these women try to break loose, and none of them succeeds in doing so. Elly protests violently at the age of eighteen, with disastrous consequences. Emily Grierson (in "A Rose for Emily") does not protest overtly, but the consequences are at least comparable to those of Elly's action. Nor does Minnie Cooper (in "Dry September") protest, and she indirectly causes the murder of an innocent person. Among all these overprotected women in Faulkner's early short stories, perhaps Miss Zilphia Gant is the most grotesque example, although she commits or triggers no crime. What she does is to perpetuate the enslavement, confinement, monotony, and boredom of a woman's life by bringing up her own daughter (or, rather, the child she pretends to be her own) in exactly the same way as she was brought up herself. Louise King in "Doctor Martino" and Mrs. Blair in "Fox Hunt" are other examples of dependent, overprotected women who are deeply troubled because of the demands of the conventional role that they have to succumb to. Even a character like Midgleston, a male, in the story "Black Music," who once was a faun and therefore never returned to his wife, asserts that she deserved their insurance money as well as a new husband; not as a result of a deeper insight in the life of many women, but simply because "Women are like that. It don't cost a man much to humor them now and then. Because they have a hard time. ..."' (289-90).

Elly has many sisters in Faulkner's fiction, and Irving Malin may be right when he finds that the heroine of "Elly" is "almost the 
sister of Temple [Drake in Sanctuary]." ${ }^{12}$ It is quite evident that Temple Drake and Elly have much in common, especially in the sense that neither of the two young women learns anything from their experience. ${ }^{13}$ In the earliest versions of the story Elly's name was Corinthia, ${ }^{\mathbf{1 4}}$ and through this name and other characteristics she is also related to the beautiful, dream-like female in the short story "The Leg," Everbe Corinthia, who casts a spell over the young boys but who dies under mysterious and tragic circumstances. And even though narcissism and certain escapist tendencies as well as hedonism and self-gratification may be detected as motivational forces behind some of the female characters' attempts to break loose, Faulkner more often than not gives sufficient motivation in the social environment to explain their behaviour. Caddy Compson, in The Sound and the Fury is thus very carefully described and explained throughout the four parts of the novel, and even for the nymphomaniac Joanna Burden (Light in August), who has an affair with a man supposed to be part Negro, motivation is found in an almost hidden and forgotten childhood and in a heritage she is deeply troubled by. Whatever Faulkner's personal opinions and views may have been, his fictional portraits of young girls in conflict with their environment and with themselves do not to any objectionable degree rely on preconceived ideas about what is typically feminine. Nor do they always condemn the girls when they refuse to adjust, or when they really are bad. Individual characters do not easily fit into a neat pattern, and Faulkners young girls emerge as individuals - not as representative types. Temple Drake's badness is, of course, unlimited and inexcusable, and she may be the very apotheosis of everything the author hated in America of his time, as Sigurd Hoel has suggested. ${ }^{15}$ But Faulkner's fictional treatment of this kind of young girls is more complicated than a one-dimensional hatred, and many of his short stories, "Elly" included, demonstrate this.

In "Elly" - presumably written before "A Rose for Emily" and "Dry September", at least originally - Faulkner's protagonist seems to require a new and totally different social pattern to make life endurable. Despite the author's admiration for the strong women who survived the war, kept families together, and carried with them traditional values to new generations (Miss Jenny in "There Was a Queen" is the most obvious example of such a woman), he also seems to understand that this "ideal woman" is conditioned by rather peculiar circumstances and hardly can be transplanted into 
a modern, urban society. In his more critical writings, his ideal is a social order where women are allowed to become useful, respected, full members of the society, and a number of the short stories in the early thirties indicate this. ${ }^{16}$ From generalizations about "how women are," Faulkner revised his stories to give his female characters individual life and he also related their destinies to their background and environment rather than to some vague notion of what is typically female or feminine. ${ }^{17}$

Faulkner's women have been described as treacherous, mischievous, dangerous, and destructive; representing some kind of inborn female quality for evil. A few of them may be described with these adjectives, but one should be careful not to make generalizations. A grouping of Faulkner's female characters into sexual versus a-sexual, ${ }^{18}$ is so gross an oversimplification that it can be overlooked. Further, to contend that Faulkner is troubled by sexually active women, or that only those beyond the menopause are understood by him, is even worse. ${ }^{19}$ One had better be cautious with what is attributed to the author and given as his opinions; furthermore, all his female characters, whether earth-goddesses, sexually warped, or pillars of an old society, should be seen in their social context to be more fully realized and understood. They must, of course, also be discussed in their fictional context, so that the narrative techniques are examined to see how the author distributes sympathy and antipathy, and to see who reacts in what ways to the different women.

"Elly" is representative of many early Faulkner stories with a young girl in opposition to her prescribed role as protagonist. A close study of "Elly" and a number of the other stories in Doctor Martino and Other Stories is a good starting point for what might become a very revealing study: the female characters in Faulkner's short fiction. ${ }^{20}$

\section{NOTES}

1 This conflict is at the core of many of the short stories in Doctor Martino and Other Stories, published in 1934. Bibliographical evidence shows that a great many of these stories were originally written before 1930. In Faulkner's first short story collection, These 13, the conflict is also present, but not so often and not so dramatically as in the second collection.

2 The stifling parental authority is also an element in "Fox Hunt," and very much so in "The Brooch" - even though a male protagonist is being "destroyed" in the latter story.

3 "Adolescence" is still unpublished; "Miss Zilphia Gant" was published in 300 copies by the Book Club of Texas in 1932 and never reprinted. A French translation appeared, however, in La Nouvelle Revue Française (April 1972). 
"Nympholepsy" is an expanded version of the sketch, "The Hill," which was published in The Mississippian in 1922. "Nympholepsy" was first published in Mississippi Quarterly, 26 (Summer 1973), 403-09.

4 One critic has briefly taken up this discussion; E. M. Kerr, "William Faulkner and the Southern Concept of Woman," Mississippi Quarterly, 15 (Winter 1962), $1-16$.

5 See Melvin E. A. Bradford, “Faulkner's 'Elly:' An Exposé," Mississippi Quarterly, 21 (Summer 1968), 180-87. This is the only extended discussion of "Elly," and Bradford finds that Faulkner condemns a certain kind of young woman which he calls the "flapper." Bradford has no sympathy for Elly, apparently because she does not fulfill her functions as a female. His condemnation of a girl like Elly is easily understood if we see it in the light of this brief quotation from Bradford's article: "Since women are the backbone of community, the vessels of its perpetuation, some aspects of their place must remain fixed if family and society are to survive. Refusal to address and act the steward of life within a framework of "given" circumstances is in no other group so serious"' (p. 180).

6 Irving Malin, William Faulkner: An Interpretation (Stanford: Stanford University Press, 1957), pp. 34-35.

7 This is the date of a letter from Scribner's Magazine where they decline the story (see James B. Meriwether, 'Faulkner's Correspondence with Scribner's Magazine," Proof, 3 [1973], p. 259). Faulkner apparently told Scribner's that Estelle Oldham, whom he was to marry in a few months, had collaborated with him on the story, which had the title "Salvage" when it reached Scribner's. This title is used in their letter and it is also used by Faulkner for the Scribner's entry on his short story sending schedule, while an early manuscript and a typescript both have the title "Selvage." - See James B. Meriwether, The Literary Career of William Faulkner: A Bibliographical Study (Authorized Re-issue: Columbia, S.C.: University of South Carolina Press, 1971), p. 175. For a discussion of Faulkner's so-called "short story sending schedule," see Appendix in this book.

Versions of this story, now found in the Faulkner collection at the University of Virginia, include a manuscript, 6 pp., entitled "Selvage," a typescript, 14 pp., entitled "Selvage," and a manuscript, 11 pp., entitled "Elly." In Faulkner's letter to Scribner's he says that the original of his typescript probably has been lost, and he therefore sends the carbon typescript, asking the magazine to hold it for him till further notice. Scribner's presumably never received the original typescript, so what they had, and probably returned to Faulkner later on, was a carbon typescript. If this is so, the extant typescript is likely to be a later version: it is a ribbon typescript, and it has a different title ("Selvage," not "Salvage"). Most probably the extant manuscript (6 pp.) and the extant typescript (14 pp.), both entitled "Selvage," represent later versions of the story than the apparently lost Scribner's TS. Faulkner often followed the practice of writing a completely new manuscript based on a refused, and later discarded, typescript.

8 Doctor Martino and Other Stories was published on May 16, 1934, by Smith and Haas in New York.

9 Page references are to the first edition of the collection, and are given parenthetically in the text.

10 "Projection" is here used in its meaning as a psychological term: to transfer to and accuse somebody of having the bad habits, thoughts, and emotions that a person is subject to himself.

$11 \mathrm{It}$ is worth noting that the recurrent references to death or lifelessness serve to underline Elly's search for life in the dead house, in the dead town. This search 
for life and love is unquestionably an important motivation for Elly's behaviour.

12 Irving Malin, William Faulkner: An Interpretation, p. 35.

13 In an unpublished study of "Elly" delivered at a short story conference at the Southern Studies Program at the University of South Carolina in 1974, Karen Endres makes this point. She also points to the fact that Faulkner uses the name Ailanthia in his story, and "Ailanthus' is the genus name of the heaven-tree, which stands at the corner of the jail yard and covers the street with its flowers in Sanctuary."

14 This can easily be found in the two early versions of the story, entitled "Selvage," now in the Faulkner collection at the University of Virginia. See also Joseph Blotner, FAULKNER: A Biography, (New York: Random House, 1974), I, 604.

15 In his preface to the Norwegian translation of Soldiers' Pay (Oslo: Gyldendal, 1932), Sigurd Hoel devotes much space to a discussion of Sanctuary and of the young girl in this book, whom he finds to be the incarnation of everything the author hates in America.

16 This is not to say, however, that Faulkner ever tries to preach some social gospel, but there is much of the outraged and disillusioned young artist siding with the losers in the competitive society in these texts.

17 Faulkner himself apparently felt that there were too many almost identical, unwarranted and unmotivated negative descriptions of female characters in his manuscripts, and he accordingly left some of them out when revising some of his stories. Abstractions about female evil, or at least a propensity for it, were left out in the final version of "A Mountain Victory," and in the final version of "Beyond." Only in stories like "Mistral" and "Divorce in Naples" do these abstractions seem to have so close affinities with the central elements of the stories that their inclusion is inevitable and necessary.

18 Irving Malin makes this kind of generalization. See William Faulkner: An Interpretation, p. 31.

19 See A. P. Libby, "Chronicles of Children: William Faulkner's Short Fiction," Diss. Stanford 1969, pp. 166-67.

20 Faulkner cannot be made directly responsible for any of the views his characters express. The consistency with which young girls reappear in his stories from around 1930 and the implied attitudes toward them which we may detect, allow us to look for certain trends in his thoughts and ideas. But judgment had better be postponed till all texts in such a study have been taken into consideration.

A study of the female characters in Faulkner's short fiction is still needed, despite the fact that two book-length studies on Faulkner's women have been published. Sally R. Page in her book Faulkner's Women: Characterization and Meaning (Deland, Fla.: Ewerett Edwards, 1972), only comments briefly on a few of Faulkner's short stories, while David Williams in his Faulkner's Women: The Myth and the Muse (Montreal \& London: McGill-Queen's University Press, 1977) treats only one piece of short fiction, viz. "An Odor of Verbena." 